\title{
Dev Omfalosel: 23 Hasta; Üç Farklı Yaklaşım
}

\section{Giant Omphalocele: 23 Patients; Three Different Approaches}

\author{
${ }^{1}$ Mustafa Alper AKAY \\ ${ }^{1}$ Kocaeli University School of Medicine, Department of Pediatric Surgery, Kocaeli, Turkey
}

Mustafa Alper Akay: https://orcid.org/0000-0003-3315-6098

\begin{abstract}
ÖZ
Amaç: Omfalosel karın ön duvar gelişim bozukluğudur. Silo yöntemi, cilt flepleri ve sentetik maddeler ile kapama tedavi seçenekleridir. Erken dönemde uygulanan cerrahi tedavilerin morbidite ve mortalitesindeki yükseklik dev omfalosellere yaklaşımda cerrahi dışı teknikleri ön plana çıkarmaktadır. Bu çalışmada omfalosel tedavisinde kullanılan primer kapatma, silo ve vakum yardımlı kapatma (VAC) yöntemlerinin avantaj ve dezavantajları karş1laştırılması amaçlanmış̧ır.
\end{abstract}

Materyal ve Metot: 2005- 2020 yılları arasında kliniğimizde tedavi edilen dev omfalosel tanıl 23 hastaya uygulanan 3 farklı tedavi yöntemi karşılaştırıldı. 14 hastaya tedavide silo yöntemi kullanıldı. 7 hastaya primer onarım yapıldı. Birincil kapama yapılan 2 hastaya meş kullanıldı. 2 hasta için ise VDK sistemi tercih edildi. Tedaviler hastanede kalış süresi, epitelizasyon süresi, enfeksiyonlar ve taburculuk sonrası sorunlar açısından tartışıldı.

Bulgular: Omfalosel tedavisinde klasik yöntemler olan silo yöntemi ve primer onarım sonrasında sepsis, ileus, gastroözefageal reflü ve solunum sistemi sorunları ile karşılaşı1ld. VDK tekniğinde, epitelizasyon ve iyileşme daha hızlı idi ve komplikasyon olarak sadece bilateral inguinal herni gelişti.

Sonuç: Diğer klasik yöntemlere göre epitelizasyonu hızlandırıcı ve enfeksiyonlardan koruyucu etkisi ile kısa dönemde iyileşmeyi sağlayan ve komplikasyonları en aza indiren VDK sistemi, dev omfalosellerin tedavisinde ilk tercih edilebilecek yöntemler arasında akla gelmelidir.

Anahtar Kelimeler: Birincil kapama; dev omfalosel; silo; VDK

\begin{abstract}
Objective: Omphalocele is the ventral body wall maldevelopment. Early surgical interventions in the treatment of giant omphaloceles (GO) can increase morbidity and mortality. In this study, it was aimed to compare the advantages and disadvantages of primary closure, silo and vacuum assisted closure (VAC) methods used in omphalocele treatment.

Materials and Methods: Three different treatment methods applied to 23 patients with giant omphalosis who were treated in our clinic between 2005 and 2020 were compared. Silo method was used in the treatment of 14 patients. Primary repair was performed in 7 patients. Mesh was used in 2 patients who underwent primary repair. The VAC was preferred for 2 patients. Treatments were discussed in terms of hospital stay, epithelization time, infections, and post-discharge problems.

Results: Sepsis, ileus, gastroesophageal reflux and respiratory system problems were encountered after the silo method and primary repair, which are the classical methods of omphalocele treatment. VAC in technique, epithelization and healing were faster and only bilateral inguinal hernia developed as a complication.

Conclusion: Minimizing complications with its effects that increase epithelization and prevent infection, VAC when other methods are considered in the treatment of giant omphalocele, it should be the first method that comes to mind.
\end{abstract}

Keywords: Giant omphalocele, primary closure, silo, VAC.

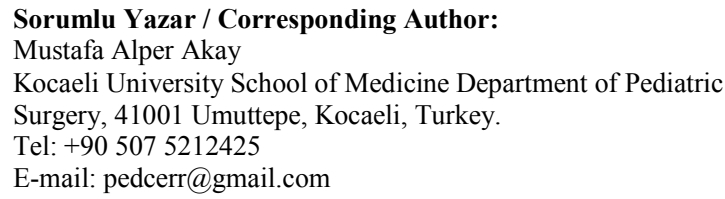

Yayın Bilgisi / Article Info:

Gönderi Tarihi/ Received: 29/09/2020

Kabul Tarihi/ Accepted: 09/10/2020

Online Yayın Tarihi/ Published: 30/12/2020

Atıf / Cited: Akay MA. Giant Omphalocele: 23 Patients; Three Different Approaches. Online Türk Sağllk Bilimleri Dergisi 2020;5(4):622630. doi: $10.26453 /$ otjhs. 801857 


\section{INTRODUCTION}

Omphalocele is a congenital anomaly characterized by herniation of the abdominal organs through the navel due to the non-fusion of muscles in the midline. Incidence is 1 case in $4000-7000$ people. ${ }^{1}$ The purpose of omphalocele treatment is to close the defect. However, large defects pose a problem. ${ }^{2}$ The abdominal cavity is underdeveloped in omphalocele. The situation that prevents safe primary closure is the disproportion between organ size and the abdominal cavity. ${ }^{3} \mathrm{GO}$ treatment is divided into two basic categories.

The first method is delayed closure without surgery, which includes topical care of the pouch. In this method, scrub is followed with regular dressing and epithelizing drugs. Eventually, a ventral hernia is created and the treatment is completed with the repair of the hernia. In the second method, the pouch is closed with a graft in the early period. Wound care is continued. In the late period, the graft is removed and the treatment is completed. ${ }^{4-6}$ When the abdominal wall is closed early in GO patients, there is a sudden increase in intra-abdominal pressure. This, in turn, reduces lung capacity as a result of compression on the chest. It causes respiratory failure. ${ }^{7}$ In newborns, abdominal volume-organ size disproportion, large abdominal defect diameter, presence of liver tissue in the sac and accompanying system anomalies make early surgical treatment impossible. - $^{8-10}$

Accompanying abnormalities in patients with omphalocele are compression of the abdominal organs, sepsis, compartment syndrome and sac infection. Inguinal hernia may develop following omphalocele repair. Increased intra-abdominal pressure may cause gastroesophageal reflux $(50 \%)$. The need for fundoplication has been reported in $4-5 \%$ of patients. $^{11}$

One of the new treatment methods is Vacuum assisted closure (VAC), a system that can be included in conservative management systems. It is a noninvasive treatment method that accelerates acute and chronic wound healing by applying negative pressure. ${ }^{12}$ Its benefit has also been demonstrated in open and infected wounds. The purpose of $12 \mathrm{VAC}$ is to keep the wound clean, reduce tissue edema, increase local blood flow, and promote healthy granulation tissue development until scheduled surgery. Another important advantage is that the use of VAC reduces the bacterial population in infected tissue. ${ }^{13}$ Moreover, this treatment option has been shown to support faster epithelization than conventional wet dressing. ${ }^{14}$

The aim of this study is to compare the advantages and disadvantages of primary closure, silo and VAC methods used in omphalocele treatment.

\section{MATERIALS AND METHODS}

The study was made in accordance with the principles of the Declaration of Helsinki. This study was approved by the Kocaeli University Ethics Committee (Date: 21/04/2015, decision no: 20/07). Twentythree patients who were treated in our clinic with the diagnosis of giant omphalocele between 2005-2020 were included in the study. The diameter of the defect was asked to be at least $8 \mathrm{~cm}$ in order to call it giant omphalocele. The defect diameter was over 10 $\mathrm{cm}$ in all patients. In all patients, the right liver lobe was within the omphalocele sac. Three different treatment approaches (primary closure, silo and VAC) applied for 23 patients were compared in terms of length of hospital stay, infections, wound healing and complications after treatment.

Central tendency measures were the method used statistically during the study. The arithmetic mean was used for gravida weeks, birth weight, defect diameter, hospitalization and follow-up periods of the patients.

\section{RESULTS}

Fourteen of the 23 patients were treated with silo method, 7 patients with primary closure, and 2 patients with VAC. Gestation weeks, birth weight, sac content, treatment methods and length of stay in the hospital of the patients are shown in table 1.

The mean of gestation week of the patients treated with the silo method was $37 \pm 4$ gestation week (gw). Average birth weight was $3000 \pm 230$ gram (gr). Defect diameters were measured as $15 \pm 3 \mathrm{~cm}$. There were spleen, intestines and right liver lobe in the sac. Patients were first followed up with nasogastric decompression. They were administered broad-spectrum antibiotics and a feeding support with total parenteral nutrition (TPN) and minimal enteral feeding was started after the observation of stool passage. A surgical intervention was not planned in the early period. They were managed with a silo in the follow-up period. Sterile daily dressing was performed with rifampicin and physiological saline painting while gently squeezing the gauze covering. Although the dressings were performed in a sterile environment, Staphylococcus 
aureus and Pseudomonas aeruginosa growths were encountered in wound cultures at different times. Two patients were diagnosed with hypothyroidism during the follow-up period, after which he received levothyroxine sodium. The average length of stay in the hospital was $140 \pm 10$ days. No second hospitalization was made in the first year of life after the hospitalization for the initial treatment. They sustained intermittent ileus episodes, one during the hospitalization period and the second after discharge. These episodes were treated with a conservative approach. They had a normal feeding and growth pattern, but they had recurrent episodes of constipation.

The second method used was primary closure. The mean of gestation week of the patients was $37 \pm 5$ gw. Average birth weight was $2900 \pm 120$ gr. Defect diameters were measured as $12 \pm 2 \mathrm{~cm}$. There were spleen, intestines, colon and right liver lobe in the sac. One patient also had a pancreas. An approach similar to that in patients with silo treatment were adopted in the first week of the follow-up. Prolene mesh was placed in 2 patients. Three patients had malrotation and were corrected during the procedure. Appendectomies were also performed during surgery. The average length of stay in the hospital was $75 \pm 10$ days. Four of the patients who underwent primary closure were admitted to the hospital with frequent attacks of aspiration pneumonia. These 4 patients were hospitalized with a diagnosis of pneumonia 3 times on average in the first year. Three patients with severe pneumonia had to receive mechanical ventilator support in the intensive care unit. One patient became oxygen dependent and left oxygen support at the age of 18 months. Gastroesophageal reflux was present in all patients. Reflux treatment was initiated after confirmed with contrast radiographs. Hiatal hernia developed in 2 patients, hernia repair and fundoplication were performed. Mesh was removed in these two patients in the same session. Hernia repair was performed in 4 patients who developed inguinal hernia. Patients who underwent primary closure required 4 separate operations: primary closure, reflux surgery, inguinal hernia surgery, and mesh removal surgery. Each patient had to be operated at least 2 times in a year. An average of 4 hospitalizations were made with the diagnosis of ileus and pneumonia. A conservative approach was used in all episodes of brittle ileus that developed in patients with primary closure, and patients benefited from the treatment. The patients are healthy now, their development is natural.
VAC therapy was applied to 2 patients. The mean of gestation week of these patients was $37 \pm 4$ gw. Average birth weight was $2700 \pm 170$ gr. Defect diameters were measured as $17 \pm 2 \mathrm{~cm}$. There were spleen, intestines and right liver lobe in the sac. Patients were first followed up with nasogastric decompression. They were administered broad-spectrum antibiotics and a feeding support with total parenteral nutrition (TPN) and minimal enteral feeding was started after the observation of stool passage. A combination of mupirocin and rifampicin was used in daily wound dressing. The patient's abdominal cavity volume increased with good epithelization, and they underwent VAC therapy after 38 days (Image 1). A negative pressure of $40 \mathrm{mmHg}$ was applied for 72 hours, and the treatment was then interrupted for 24 hours. During this period, wound dressing was performed with mupirocin+rifampicin+chlorhexidine acetate tulle grass dressing (Bactigrass, Smith\& Nephew, Canada). It was observed that epithelization starting from the edges of the sac progressed rapidly from the 3rd dose (Image 2). Ten applications were performed in total. The debridement of necrotic tissues was performed before each VAC procedure. Wet dressing was performed with an emollient gel in the last four applications. The patients was discharged at the end of 90th and 98th days when the sac epithelization was completed and a ventral hernia developed (Image 3 ). There was no reproduction in the wound cultures taken at different times with the dressings applied every 3 days. They were no further hospitalization was required apart from the admission for the initial treatment. Ventral hernia and bilateral inguinal hernia that developed during the hospitalization period were repaired in a single session of surgery. The patients had a normal feeding and growth pattern in the last follow-up visit. At the age of 1, ventral hernia was repaired.

\section{DISCUSSION AND CONCLUSION}

The timing of surgical repair in GO patients is controversial. There are few studies that can help in this regard.

Gradual closure methods have been developed to alleviate the complications of early surgical repair. ${ }^{16}$ GO therapy largely depends on the size of the defect, the lung condition, and the severity of concomitant anomalies. ${ }^{17}$ Despite advances in neonatology, despite optimal anesthesia and surgery, mortality can reach up to $25 \%$ in infants with GO. 6,16

Complications resulting from primary closure of giant omphaloceles are high. In 2011, Eijck et al. in 
his study, ${ }^{18}$ the average postoperative herniation their rate was $58 \%$ in primary closure and $9 \%$ in delayed closure. In our study, when the length of hospital stay was compared, earlier discharge was possible in the primary occlusion group. However, deterioration in lung functions, recurrent ileus attacks and hernia due to the use of grafts have been more frequent cases requiring hospitalization than conservative methods.

Bauman et al. ${ }^{19}$ In a study carried out by, an increase in morbidity was observed in half of the patients as a result of the prolongation of the fascia closing time despite the application of betadine and antisepsis in the late surgical method. In our study, Staphylococcus aureus and Pseudomonas aeruginosa were observed in the wound cultures taken from the patients in the group treated with the silo method. On the other hand, there was no growth in the cultures of the patients who received VAC treatment. This has brought VAC treatment to the fore among conservative approaches.

Topical therapies used for delayed closure in conservative follow-up in GO care have greatly improved in recent years. Povidone-iodine is effectively recommended. However, thyrotoxicosis was reported in one case. ${ }^{20}$ One of our 14 patients (treatment with silo) also developed hypothyroidism. However, Betadine and Silverdin are currently known as the most widely used topical medications. $^{21,22}$

The effects of three different treatment approaches used in the study on mortality werepared. Although the repair with silo management prevents the development of an intraabdominal compartment syndrome, the complications associated with prolonged parenteral nutrition, particularly sepsis are the most important causes of mortality and morbidity. In a study by Maksoud-Filho JG et al., ${ }^{15}$ the rate of mortality was $9 \%$ in the patients undergoing a primary repair and $25 \%$ in the patients undergoing repair with the silo closure technique.

In our study, it has some limitations. The study was conducted with a retrospective review patient files. Therefore, it was not possible to reveal congenital malformations in detail. The most important limiting factor in our study was that the number of patients treated with VAC was 2. If the number of patients is increased, it will be possible to reach more precise results.

As a result, it was concluded that VAC has no significant effect on the duration of hospital stay, accelerates epithelization, increases intraabdominal vol- ume in parallel with increasing epithelization, protects against infection and sepsis without changing pressure dynamics. Apart from these positive effects, it is a VAC method that has no disadvantages compared to other methods. The study concluded that VAC may be an effective option in omphalocele treatment, superior to other treatments.

Ethics Committee Approval: Our study was approved by the Kocaeli University Ethics Committee (Date: 21/04/2015, decision no: 20/07).

Conflict of Interest: No conflict of interest was declared by the authors.

Author Contributions: Concept - MAA; Supervision - MAA; Materials - MAA Writing -MAA

Peer-review: Externally peer-reviewed.

Acknowledgement: The author thank to Prof. Dr. Gülşen Ekingen Yıldız for their support of the study.

\section{REFERENCES}

1. Binet A, Scalabre A, Amar S, et al. Operative versus conservative treatment for giant omphalocele: Study of French and Ivorian management. Ann Chir Plast Esthet. 2019;65:147-153.

2. Roux N, Jakubowicz D, Salomon L, et al. Early Surgical Management for Giant Omphalocele: Results and Prognostic Factors. J. Pediatr. Surg. 2018;53(10):1908-1913.

3. Pelizzo G, Maso G, Dell'Oste C, et al. Giant omphaloceles with a small abdominal defect:prenatal diagnosis and neonatal management. Ultrasound Obstet Gynecol. 2005;26:786788.

4. Bauman B, Stephens D, Gershone H, et al. Management of giant omphaloceles: a systematic review of methods of staged surgical vs. nonoperative delayed closure. J Pediatr Surg. 2016;51:1725-1730.

5. Ein SH, Langer JC. Delayed management of giant omphalocele using silver sulfadiazine cream: an 18-year experience. J Pediatr Surg. 2012;47:494-500.

6. Akinkuotu AC, Sheikh F, Olutoye OO, et al. Giant omphaloceles: surgical management and perinatal outcomes. J Surg Res. 2015;198:388392.

7. Skarsgard ED: Immediate versus staged repair of omphaloceles. Semin Pediatr Surg. 2019;28:8994.

8. Duggan E, Puligandla PS. Respiratory disorders in patients with omphalocele. Semin Pediatr Surg. 2019;28:115-117. 
9. Dingemann C, Sonne M, Ure B, Bohnhorst B, von Kaisenberg C, Pirr S. Impact of maternal education on the outcome of newborns requiring surgery for congenital malformations. Plos One. 2019;14(4): e0214967.

10. Chakhunashvili DG, Lomidze N, Karalashvili L, Kikalishvili L, Chakhunashvili K, Kakabadze Z. Challenges and management of congenital abdominal wall defects (Review). Georgian Med News. 2018;24-33.

11. Mehmet Eliçevik. Karın Ön Duvarı Anomalileri. Turk Arch Ped. 2010;45 Suppl:29-34.

12. Ozkan B, Markal Ertas N, Bali U, et al. Clinical Experiences with Closed Incisional Negative Pressure Wound Treatment on Various Anatomic Locations. Cureus. 2020;12(6):e8849. doi: 10.7759/cureus.8849

13. Ahmet Demir at al. Topikal Negatif Basınç (Vakum yardımlı kapama) (VAC) uygulamalarımız. Türk Plast Rekons Est Cer Dergisi. 2006;14(3):171-177.

14. Seidel D, Diedrich S, Herrle F, et al. Negative Pressure Wound Therapy vs Conventional Wound Treatment in Subcutaneous Abdominal Wound Healing Impairment: The SAWHI Randomized Clinical Trial. JAMA Surg. 2020;155 (6):469-478.

15. Maksoud-Filho JG, Tannuri U, Da Silva MM, et al. The outcome of newborns with abdominal wall defects according to the method of abdominal closure: the experience of a single center. Pediatr Surg Int. 2006;22:503-507.

16. Charlesworth P, Ervine E, McCullagh $\mathrm{M}$. Exomphalos major: The Northern Ireland experience. Pediatr Surg Int. 2009;25:77-81.

17. Pereira RM, Tatsuo ES, Simões E Silva AC, et al. New method of surgical delayed closure of giant omphaloceles: Lazaro da Silva's technique. J Pediatr Surg. 2004;39:1111-1115.

18. Van Eijck FC, de Blaauw I, Bleichrodt RP, et al. Closure of giant omphaloceles by the abdominal wall component separation technique in infants. J Pediatr Surg. 2008;43:246-250.

19. Bauman B, Stephens D, Gershone H, et al. Management of giant omphaloceles: a systematic review of methods of staged surgical vs. nonoperative delayed closure. J Pediatr Surg. 2016;51:1725-1730.

20. Malhotra S, Kumta S, Bhutada A, JacobsonDickman E, Motaghedi R. Topical IodineInduced Thyrotoxicosis in a Newborn with a
Giant Omphalocele. AJP Rep. 2016;6(2):e243e245. doi:10.1055/s-0036-1584879

21. Eltayeb AA, Mostafa MM. Topical treatment of major omphalocoele: Acacia nilotica versus povidone-iodine: a randomised controlled study. Afr J Paediatr Surg. 2015;12:241-246.

22. Tran DA, Truong QD, Nguyen MT. Topical application of povidone-iodine solution (Betadine) in the management of giant omphaloceles. Dermatology. 2006;212:88-90. 
Table 1. Treatment groups and their distribution and characteristics.

\begin{tabular}{|l|c|c|c|c|c|c|}
\hline $\begin{array}{l}\text { Treatment } \\
\text { method }\end{array}$ & $\begin{array}{c}\text { Patient } \\
\text { count } \\
\text { (Total=23 } \\
\text { patients) }\end{array}$ & $\begin{array}{c}\text { Gesta- } \\
\text { tion } \\
\text { week } \\
\text { (gw) }\end{array}$ & $\begin{array}{c}\text { Birth } \\
\text { weight } \\
\text { (gr) }\end{array}$ & $\begin{array}{c}\text { Defect } \\
\text { diameter } \\
\text { (cm) }\end{array}$ & $\begin{array}{c}\text { Sac } \\
\text { Content }\end{array}$ & $\begin{array}{c}\text { Length of } \\
\text { stay in the } \\
\text { hospital } \\
\text { (days) }\end{array}$ \\
\hline Silo & 14 & $37 \pm 4$ & $\begin{array}{c}3000 \\
\pm 230\end{array}$ & $15 \pm 3$ & $\begin{array}{c}\text { Spleen, Liv- } \\
\text { er, Intestine }\end{array}$ & $140 \pm 10$ \\
\hline Primary Clo- & 7 & $37 \pm 5$ & $\begin{array}{c}2900 \\
\pm 120\end{array}$ & $12 \pm 2$ & $\begin{array}{c}\text { Spleen, Liv- } \\
\text { er, Stomach, } \\
\text { Intestine, } \\
\text { Colon, Pan- } \\
\text { creas }\end{array}$ & $75 \pm 10$ \\
\hline VAC & 2 & $37 \pm 4$ & 2700 & $17 \pm 2$ & $\begin{array}{c}\text { Liver, Intes- } \\
\text { tine, Spleen }\end{array}$ & $94 \pm 4$ \\
\hline
\end{tabular}

gw: gestation week; gr: gram; cm: centimeter 


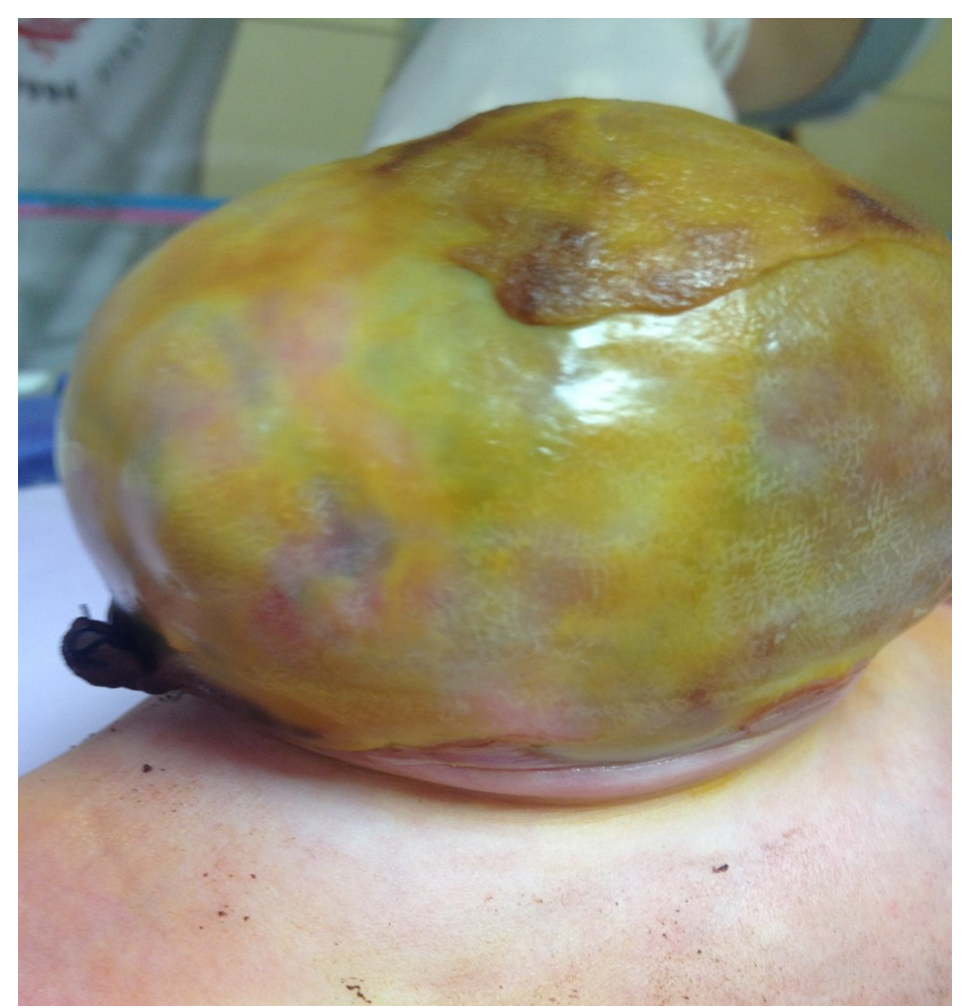

Image 1. Before VAC (Day 38). 


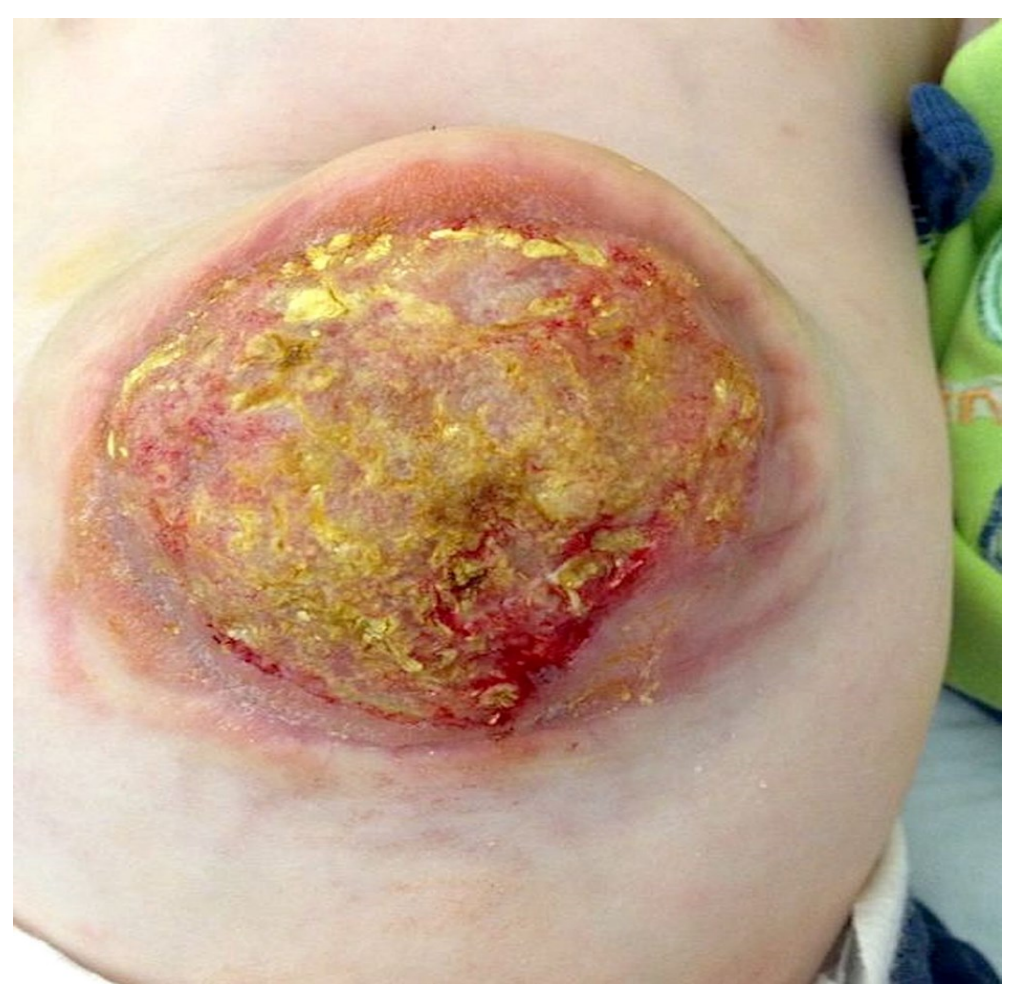

Image 2. After 3th dose of VAC. 


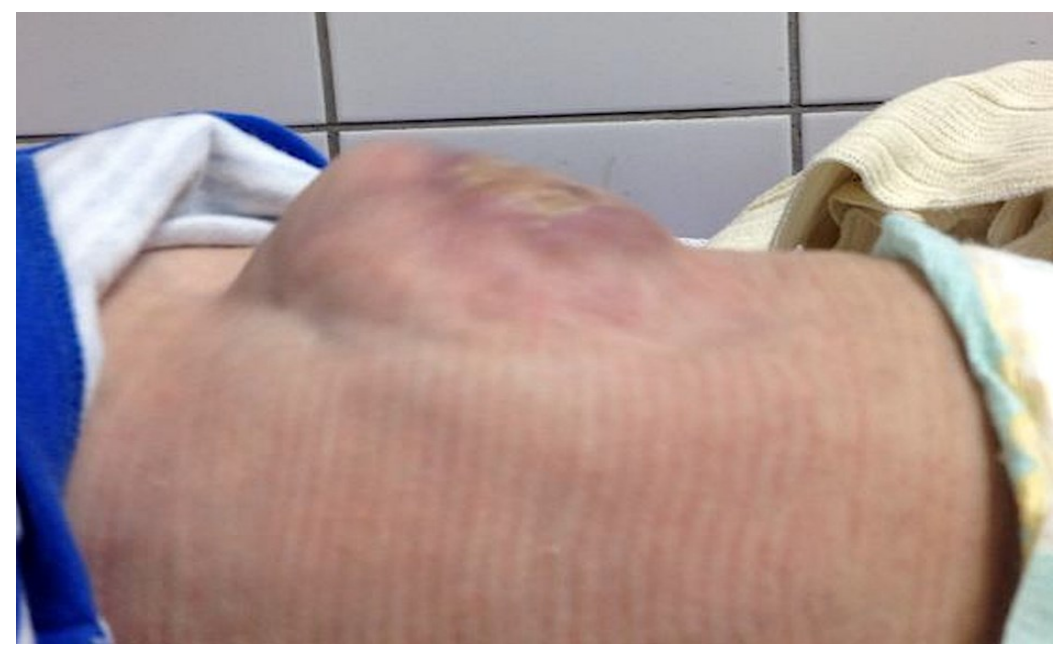

Image 3. Formed ventral hernia. 